\title{
Revaluing Mimeographs as Historical Sources $^{1}$
}

CURATORS ARE PARTNERS with printing historians, collectors, and conservators, as well as with communities, in selecting, preserving, and interpreting cultural heritage. Uncovering the role of a technology such as mimeography reveals more than a history of a specific machine or technical process. It secures a better understanding about social experience by authenticating accounts about how diverse groups communicated with their own communities and to others. Special collections professionals need to be archaeologists to recover evidence from and to best preserve 20th-century publications. Current tools for studying recent print artifacts are insufficient. Thus, collaborating to generate methods for analysis is an essential part of extending the range of social experiences that special collections should document.

Techniques applied to description of hand-press-era literary works can be turned toward popular duplication processes of the last century. Bibliographical analysis is a particularly good tool for verifying aspects of a publication's production history. Close examination of material objects tests other forms of evidence and aids in identifying potential concerns regarding handling and care. This article takes as an example the initial issues of The Ladder, produced by the Daughters of Bilitis from 1956 to 1972, and suggests a route for identifying duplication methods during a period in which many reproduction technologies were available. Most closely identified with mimeography, The Ladder provides evidence of a spectrum of production techniques rather than just one method in the first year of its existence. That diversity points to a greater variety of papers and inks that need to be assessed for best care of materials. It also testifies to the pragmatic approaches that the Daughters of Bilitis took in establishing a publication that proved to be a foundation for the American LGBT movement.

1. This paper offers revised analysis and expands upon a portion of the author's keynote address "Revaluing Mimeographs and Other Obsolete Things: An Introduction to Media Archaeology," presented at the Rare Books and Manuscripts Section Pre-Conference in Minneapolis, Minn., June 25, 2013. The author is grateful to anonymous reviewers who provided comments that assisted in narrowing the focus of this paper; to Nina Mamikunian for research assistance and Brian Cassidy, Laura Micham, and James Ascher for advice on this article; to the Minnesota Population Center (R24HD041023) at the University of Minnesota for writing support with the larger project of which this paper is a part; and to Lisa Vecoli of the Jean-Nickolaus Tretter Collection in Gay, Lesbian, Bisexual and Transgender Studies at the University of Minnesota for access to The Ladder and other historical materials. Errors of analysis are solely the author's. 


\section{The Mimeograph}

In 1876, Thomas Edison patented the first of several inventions related to what would become known as the Mimeograph machine. Albert B. Dick recognized the potential for reshaping Edison's autographic invention into an automatic printing machine more recognizable to both printing and business offices. Dick partnered with the inventor to market the machine as Edison's Mimeograph through his own firm of A.B. Dick Company. ${ }^{2}$

A.B. Dick Company became the most prominent U.S. supplier of machines and ancillary equipment for office duplication by the early 20th century. Suppliers in the United States, the United Kingdom, and Europe developed their own duplicating systems with distinct machine designs and stencils, pens, and inks: Mimeographs in the United States, Roneos in the United Kingdom, and Gestetners in United Kingdom and Europe. In the United States, stencil duplication became widely known as mimeography, regardless of whether prints were produced on a Mimeograph machine.

A.B. Dick Company made critical improvements such as a rotary design and adapting the stencil through which ink flowed. The company required machine purchasers to sign a licensing agreement that stipulated use of only its own paper, ink, stencils, and implements for authorized operation. Affirmed in 1912 by the Supreme Court, the "tying" arrangement allowed the company to offer its machines widely at a relatively low cost, with an assurance that the sale of supplies would generate a revenue stream. ${ }^{3}$

The firm promoted mimeography as an office-friendly duplication system, with expenses proportional to actual use. Advertisements in popular publications promoted the speed, ease, and economy of the technique. A 1908 graphic noted that users could generate personalized communication as well as copious duplicates. One decade later, the company lauded the machine's ability to integrate illustrations with typewritten copy while producing 1,000 copies in a short time. By the early 1940s, A.B. Dick Company emphasized the protection that in-house production gave, running an ad with the text, "It will keep your secrets. Operate it yourself." ${ }_{4}$

2. Barbara J. Rhodes and William W. Streeter outline the development of a range of duplication processes, including mimeography, in pp. 123-67 of their comprehensive work Before Photocopying: The Art and History of Mechanical Copying, 1780-1938 (New Castle, Del.: Oak Knoll Press, 1999).

3. In the case of Henry v. A.B. Dick Co., 224 U.S. 1 (1912), the Supreme Court ruled against a vendor who had supplied ink to a woman for use on a Rotary Mimeograph produced by A.B. Dick Company. The court upheld that sale of the machine, rather than leasing of it, did not limit the right of the patentee to proscribe certain uses of the machine because of the contractual agreement with the purchaser. (The firm commonly operated under the names A.B Dick Company, A.B. Dick Co., and A.B. Dick.)

4. "Tell It Quickly," A.B. Dick Company Mimeograph Circular advertisement, Harper's Magazine Advertiser (1908); "She draws it on a dark-blue stencil...," Edison Dick Mimeograph advertisement, Life Magazine (1918); and "A Good Year for Ben Franklin’s Wisdom," A.B. Dick Co. Mimeograph Duplicator ad, Life Magazine (1941). 
Mimeography captured the imagination of potential self-publishers. Advertised as simple in design and operation, the equipment proved accessible to nonprofessional printers. Writers, activists, and other amateurs learned printing skills or gained access to friendly machine owners through the widespread presence of these machines in offices around the country. The skills to run a machine were readily gained through programs run by the A.B. Dick Company or training on the job. These low-cost, reliable machines for duplicating one's own original material have been associated closely in fact and public perception with publishing undertaken outside commercial printing channels, as well as through mainstream printers and business offices. The word "mimeograph" has taken on a meaning beyond works produced on a Mimeograph machine.

A self-published work escaped the scrutiny applied to works printed at a formal production facility, even for the U.S. government. Critics of the executive branch of the U.S. government in the early 20th century sought to restrict the use of mimeography by agencies for their own government publications. The Printing Reform Act of 1919 attempted to assert Congressional control over material disseminated by the Committee on Public Information, headed by George Creel, produced outside the Government Printing Office. Even within the government, mimeography has been linked to tensions about support for war efforts and control over content disseminated to the public. ${ }^{5}$

By the 1950s, mimeography had long been a mainstream printing practice, though often coupled with a sensibility of self-determination. The A.B. Dick Company supplied a range of duplicating machines to the printing industry, offices, and other settings in the 1950s. In addition to selling mimeograph machines and supplies, it competed aggressively in the market for photolithographic printing equipment. The addition of photocopying machines to its product line of mimeography, spirit duplicating, and lithographic equipment and supplies made A.B. Dick essential to self-publication. For the next three decades, the firm dominated the market for compact, reliable presses upon which the growing quick-print industry in America relied, with close connections to in-plant printing as well as in-office duplication, due to the breadth of its offerings. ${ }^{6}$

The ease of access to mimeography across the printing industry, business offices, and community organization settings blurred boundaries for the social produc-

5. John Walters, "Politics as Usual: The Joint Committee on Printing and Executive Agency Publishing, 1919-1921," Government Publications Review 20 (1993): 41-59.

6. For more on the diffusion of printing operations into commercial establishments and gender roles in the printing industry during this period, see Haven Hawley, "Economic Growth, Employment, and Access: A Case Study of Technological Change in the Printing Industry," research paper for the graduate course "Seminar on Industrial Modernization," Fall 1997, Georgia Institute of Technology. Available online at https: / / independent.academia.edu/HavenHawley. [accessed 13 January 2014]. 
tion of print. Accessible and localized, this form of self-publication connoted rejection of external control over a community's message and production of self-determined cultural content. Though such practices were not exclusive to amateur producers or underground presses, mimeographs have become the stuff of legends for those studying alternative publishing or the Mimeo Revolution. From the Black Arts Movement to feminist presses, mimeography linked marginalized groups to a recurring motif of independence and aided in the construction of community.

Actual and imagined mimeography became a motif of American discourse. Yet self-production and the marks of authenticity that amateur production lent to an organization sometimes existed in tension with the pressures that authors or organizations felt to generate a sense of substantial identity through print. Professionalizing the appearance of a publication at times lay at odds with alternative or artistic expression.

As organizations institutionalized and sought to respond to reader demand for better-looking publications, they sometimes outsourced aspects of production. Volunteers with access to ordinary office supplies could extend editorial control by preparing stencils, even when printing occurred in a commercial establishment. Additional technologies becoming available through the quick-print industry and larger offices, such as photostatic printing, further encouraged interpenetration of the roles of authors or editors with physical production of print. The association of mimeography with amateurism opened the way for ambivalent meanings of its use. Did a newsletter have to be produced entirely in one's own office to be self-published? Could the term "mimeography" be used to describe other forms of self-generated production?

The proximity of many forms of duplication to nonprofessional producers and end users encouraged popular usage of the word "mimeography" to become an umbrella term for printing techniques available outside print shops. Spirit duplicating and mimeography have especially been confused with one another, perhaps because of their frequent presence in copying rooms for noncommercial locations. That association became quite strong as newer forms of duplication superseded both from the 1960s onward. Spirit duplicating and mimeography can be distinguished from one another, however.

Many people of a certain age recall—perhaps too fondly—the smell of spirit duplicating from course assignments printed in the school duplicating office. Spirit duplicating typically used a purple colorant and solvents, producing a distinctive chemical smell and as many as several hundred copies. Those caring 
for rare print from the 20th century have seen the results of fugitive aniline printing and struggle to preserve original format while retaining legible text and illustrations. Though a somewhat more difficult technology to master than mimeography, spirit duplicating has somehow been remembered otherwise. The institutional contexts in which we have come into contact with spirit duplicating have been familiar-the classroom, church, or community center as chief examples.

Mimeography involves creating a stencil from a paper covered in a waxy surface. A typewriter (without its ribbon) or a stylus can be used to strike or draw upon the stencil, effectively pushing the wax to either side and revealing the tissue paper substrate. Removing the wax allows ink from the machine's printing cylinder to seep through the stencil in selected areas, which forms the image to be transferred. Too much pressure in preparing the stencil can rip the tissue, resulting in ink blobs in the bowls of letters where closed areas have been removed completely. Those preparing stencils avoided excessive underlines or cuts of closed circles that weakened the master. Complex layouts required careful preparation and handling, at the risk of producing a stencil too fragile to print. Machines printed large areas of color poorly, as the semifluid ink flowed too freely through such cuts. A skilled operator could reuse a quality stencil and produce excellent results consistently, given the proper type of absorbent paper and supplies.

In contradistinction, spirit duplicating uses a second sheet bearing pigmented wax as a source of colorant rather than as a stencil. Typing or drawing on a master with its matched sheet transfers pigment to the verso of the master. During the printing process, solvent applied to the master dissolves enough colored wax to reproduce the original image upon contact. The aniline dyes (particularly purple), damp sheets, and solvent odor of spirit duplicating are often recalled as mimeography by adults who received wet quiz copies from grade school teachers and others.

Distinguishing between spirit duplicating and stencil duplicating allows for better recognition of preservation needs associated with materials produced without consideration of their longevity. The coated paper and fugitive ink of spirit duplicating are especially vulnerable to deterioration and illegibility as ink fades. Stencil reproduction applied viscous, typically oil-based ink, to absorbent paper. Produced in a variety of grades but most often as 20-pound stock with slight sizing and surface intended to provide time for ink to be absorbed, these papers were not intended for permanence. Mimeograph paper could be procured through printers handling relief or lithographic work, and ink-though best when matched to the type of 
paper and stencil—might even be produced through the dilution of book printing ink with turpentine or gasoline. ${ }^{7}$

\section{Daughters of Bilitis}

Formation of the Daughters of Bilitis and the organization's publication agenda profoundly shaped the formation of lesbian communities and individual identities in the years after World War II. In today's era of assimilative strategies for advancing gay and lesbian rights, the organization seems particularly current. "What was later called 'politically correct' happened by chance, not design," according to Del Martin and Phyllis Lyon, cofounders of the Daughters of Bilitis. Production details of The Ladder, a publication that became the first national lesbian magazine with broad distribution, suggest that the birthing of social organizations is more complex than the narratives that come to define a movement. ${ }^{8}$

The two women joined with three other couples to found Daughters of Bilitis in 1955 after finding it difficult to form a social life that included other lesbians, simply for lack of information about where such people might be. Plucked from a minor French poet's work, the name "Bilitis" provided a discreet reference to Sappho and the Isle of Lesbos. Early members sought protection through strictly controlled access to the group, but maintaining and growing membership forced the group to opt for a more public strategy, engaging directly with a society largely hostile to lesbians.

They soon decided on a plan that included public discussions about homosexuality and production of a newsletter. Meetings offered face-to-face opportunities for networking and for injecting a more positive perspective about homosexuality into public spaces. In time, the newsletter became a magazine. Produced initially on a mimeograph machine and mailed to a growing list of recipients, The Ladder became a key communication avenue for connecting women (and a few men) who challenged heterosexual normativity and for generating a sense of community across many sectors of lesbian identity until its final issue in 1972 . The publication followed the first known lesbian publication in the United States, VICE VERSA, produced briefly just after World War II by "Lisa Ben" on a typewriter with multiple carbons. ${ }^{9}$

7. Ian Batterham, The Office Copying Revolution: History, identification and preservation (Canberra: National Archives of Australia, 2008), 70; L.C. Young, Materials in Printing Processes, The Library of Printing Technology (London and New York: Focal Press, 1973), 103; American Paper and Pulp Association, The Dictionary of Paper (New York: American Paper and Pulp Association, 1940), 230; Bill Stencil, Handbook of Mimeograph Technique (Mena, Ark.: Commonwealth College, 1937), 26-27.

8. Del Martin and Phyllis Lyon, "Daughters of Bilitis and the Ladder that Teetered," Journal of Lesbian Studies 5.3 (2001), 114.

9. Devising a pseudonym from an anagram of "lesbian," "Lisa Ben" wrote and produced VICE VERSA in small batches of a single front sheet and a handful of carbon copies, distributing it for free. See Marcia M. Gallo, Different Daughters: A History of the Daughters of Bilitis and the Rise of the Lesbian Rights Movement (New York: Carroll \& Graf Publishers, 2006), xxxiii-xxxv. Gay men's publications included ONE (1953-1972) and the Mattachine Review (1955-1966). 
The Daughters of Bilitis proved especially attuned to the need for a professional appearance for publications. The first DOB constitution, adopted in 1955, stipulated that chapter newsletters be printed by mimeograph or offset machines, contain information about events of local interest (but not policy statements), and be distributed in the surrounding area only. Expectations for production of the national newsletter may be inferred from these instructions. ${ }^{10}$

The Ladder served as "a sounding board from the variant's point of view," establishing a forum in which the ideas of an individual reader could be shared with others. The publication articulated key points of education and advocacy. Education required access to information for lesbians and the public so that perceptions could be corrected. At the same time, members of the lesbian community needed to allow their lives to be studied to facilitate more accurate information about themselves. This tenet positioned the group as the only credible source about the real lives of lesbians in the United States. By asserting that greater study of penal codes gave homosexuals the ability to insist on revisions through existing legal channels, editors situated the Daughters of Bilitis as an agent of change even as it sought inclusion through existing societal mechanisms. ${ }^{11}$

On the first anniversary of The Ladder, the editor wrote of the tremendous effect upon interest in the group's activities that distributing the publication had produced. Attendance at public events had increased to 45 women. Starting with a paid subscription list of 17 (boosted to a total of 200 by judicious addition of the names of professionals and acquaintances who might be supportive), The Ladder entered its second year with about 400 subscribers. ${ }^{12}$

Production of The Ladder in that first year has become intimately associated with mimeography. Though careful histories of the Daughters of Bilitis have noted production information about only a few issues, self-publication in specific conjunction with mimeography has become common lore for The Ladder and other early gay movement publications. In the case of The Ladder, mimeography recurred as a production method more often in early years than did other techniques. The ready familiarity of duplication systems to women who had experience in business offices, educational institutions, and community organizations has aided that association.

A preoccupation with initial practices - and a willingness to assume continuity from those firsts - unfairly simplifies the establishment of a publication that

10. Daughters of Bilitis Constitution and Bylaws, 1955, Box 1, Daughters of Bilitis Records, 19551986, Record Number 1946, UCLA Libraries and Collections [hereinafter DOB Records].

11. The Ladder 1.3 (Dec. 1956).

12. Del Martin, “Growing Pains Don't Hurt!” The Ladder, 2.1 (Oct. 1957): 4-6, 27. 
challenged existing social beliefs. Rather, analysis of the printing processes used complicates the story of how founders navigated the difficulties of producing a publication that gave life to the emerging organization. First-hand knowledge, editorial comments, and physical evidence suggest that the production process was more complex and has yet to be accurately documented.

A founder of Daughters of Bilitis noted in a 2002 panel discussion with the GLBT Historical Society in San Francisco that mimeography played a key role in getting the publication off the ground. The first issue was produced on a machine owned by the Mattachine Society. ${ }^{13}$ Martin and Lyon outlined a brief production history of The Ladder in a co-written article that acknowledged the use of the Mattachine mimeograph machine for the first three issues. They noted that, for a time afterward, lesbians in the sign printing office at Macy's printed The Ladder off the clock, using their employer's machinery and paper supplied by Daughters of Bilitis. Their version overlaps with scattered references to production processes found in DOB records held by UCLA Libraries. ${ }^{14}$

The September 1956 meeting minutes of the Daughters of Bilitis discussed the costs associated with producing the first issue of The Ladder, with replacement of mimeograph ink and staples owed to the Mattachine Society. The organization retained paper for additional production but determined to change to a lighter cover. By December, the president of DOB corresponded with a supporter about the organization's production equipment, phrasing information about "our mimeograph machine" and "our press," in a manner that suggested greater control over capital assets than the DOB actually had and indicated a close relationship with the Mattachine Society. The letter relayed good news. "We now have access to a multilith machine which will enable us to raise our production and the work will be much speedier," wrote D. Griffin. The better machine would make a more pleasing publication, she added. ${ }^{15}$

"By the third issue, The Ladder graduated from the none-too satisfactory (to put it mildly) mimeographed newsletter to a bona fide printed format - the printing took place before and after working hours in a local commercial establishment unbeknownst to the proprietors," according to the editor, writing on the publication's first anniversary. ${ }^{16}$

13. Lyon and Martin joined a panel titled "First Time in Print" held by the GLBT Historical Society and the Hormel Center at the San Francisco Public Library in 2002. They discussed the cover design and printing of the first issue in a clip from the panel, available online at http:/ youtu.be/oEsluZvBm84 [accessed 10 January 2014].

14. Martin and Lyon, "Daughters of Bilitis and the Ladder that Teetered," 114.

15. Daughters of Bilitis Meeting Minutes, Sept. 25, 1956, Box 8, DOB Records. Correspondence from D. Griffin to Charlotte, Dec. 10, 1956, Box 5, DOB Records.

16. Martin, "Growing Pains Don't Hurt!" 5. Non-italicization or capitalization of The Ladder follows document style and has not been regularized. 
In early 1957, problems arose with the printing arrangement. Reliance upon externally owned and professional equipment limited the number of DOB members who could duplicate copies, even if volunteers still could assist with editorial and mailing activities. In the middle of February 1957, the press operator suffered a serious injury during production. A correspondent wrote, "Sandy almost cut her finger off trimming THE LADDER last week and is incapacitated for a couple of months. It is a sad blow as she is the one who prints the magazine." ${ }^{17}$

Martin and Lyon recalled near-discovery of printing in progress as a turning point in shifting back to in-house production. As DOB members produced The Ladder for an uncited issue, a supervisor appeared, seeking the forewoman. One assistant distracted the supervisor while another placed herself in the line of sight of printed sheets, creating enough commotion to encourage the man to return later with his inquiry. With additional funds coming into the coffers of Daughters of Bilitis, the organization turned to Pan-Graphic Press for reproduction at a special rate from the firm, which maintained a close relationship with the Mattachine Society. Martin and Lyon's recollection suggests that DOB returned to mimeographed production. They describe volunteers as helping out with distribution and with making stencils. ${ }^{18}$

Artifact analysis and contemporary evidence may be able to help clarify the retrospective memory of participants in this history-making venture. Reference sources for forensic analysis provide limited assistance (see Bibliographical Essay). The Ladder's first anniversary issue noted that the change from mimeography to multilith occurred "By the third issue," making it seem as though only the first two issues were mimeographed. A note about stencil-making by volunteers after the shift to Pan-Graphic for production may refer to tasks related to organizational communication rather than The Ladder. A photo showing Barbara Gittings next to a mimeo machine in the New York DOB office around 1959 confirms continuing use of the technology in that chapter's office, sustaining the importance of self-production to the organization. However, a commercial printing firm producing serialized matter would almost certainly have employed offset lithography. An undated image exists of just such a press related to Pan-Graphic operations, of the type one might expect in a commercial establishment. ${ }^{19}$

Examples from volume one issues of The Ladder held by the University of Minnesota confirm a transition to photolithography. Figure 1 shows magnifications of

17. [Unsigned] to June and Dottie, Feb. 20, 1957, Box 3, DOB Records.

18. Martin and Lyon, "Daughters of Bilitis and the Ladder that Teetered," 114-15.

19. Gallo, Different Daughters, center inset photos; and Nate Schulman, "Getting Graphic: The History of Graphic Design in Queer Activism," slide 19; presentation available online at http:/ / issuu.com/ nateschulman/docs/getting_graphic [accessed 13 January 2014]. 
the letter T reproduced through typewriting, mimeography, and offset photolithography. Figure 2 depicts the same letter on the first text page of issues 3, 6, and 7 of volume 1 of The Ladder. ${ }^{20}$

\section{Figure 1.}

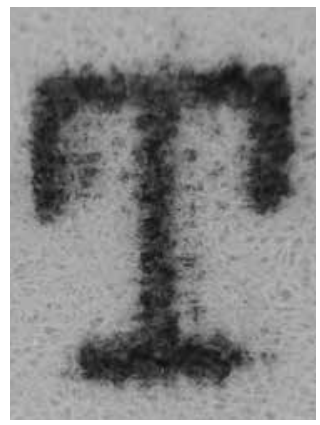

Typewriter

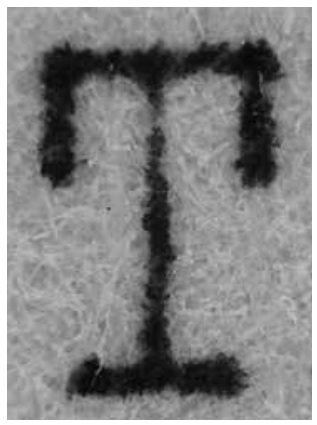

Mimeography

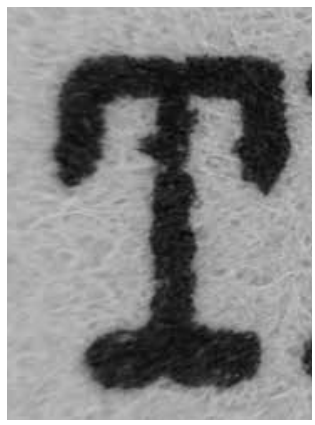

Photolithography

Figure 2.

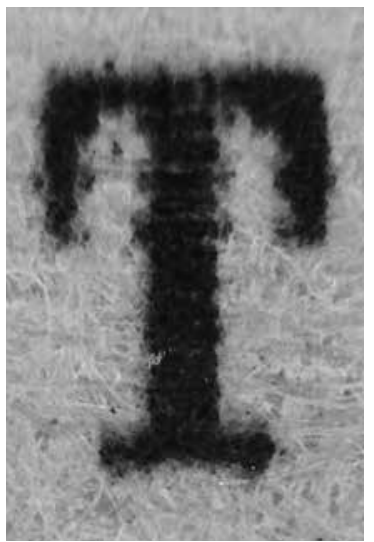

Issue 3 (December 1956)

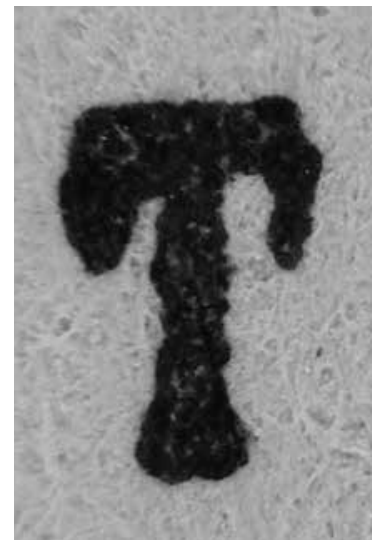

Issue 6 (March 1957)

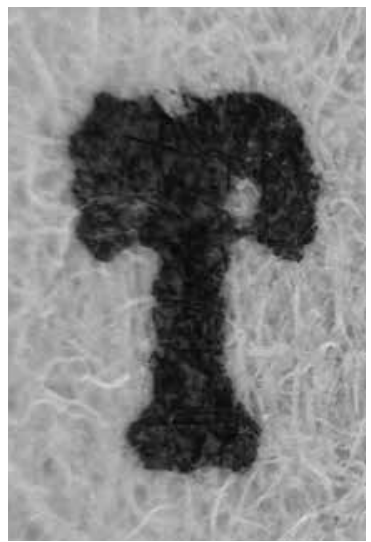

Issue 7 (April 1957)

The third issue presents a difficult identification challenge. Magnification of a letter from the December 1956 issue reveals small dots shading the outline, as depicted in this letter T, which particularly shows these features where stem and arms meet. These regularly spaced dots are difficult to reconcile with mimeography and seem more typical of a type hammer hitting an inked ribbon into a sheet of paper. In

20. Images are magnified with slight adjustments for lighting differences. Sources for Figure 1: typewriter, Underwood Universal owned by author; mimeography and photolithography, duplication samples in Mimeograph Publishing: Sample Pages of Texts, Manuals, Outlines, Lectures and Syllabuses; Mimeographed, Printed, and Published (Minneapolis: Burgess-Roseberry Company, 1933?). Sources for Figure 2: first text pages of The Ladder, 1.3 (Dec. 1956), 1.6 (Mar. 1957) and 1.7 (Apr. 1957), held at the Jean-Nickolaus Tretter Collection in Gay, Lesbian, Bisexual and Transgender Studies at the University of Minnesota. 
contrast to the characteristic marks of a typewritten document, a stencil prepared for mimeography would be unlikely to convey casual marks lying outside the letter impression to a final printed sheet.

In production of a stencil, a tool such as a stylus, pointed wheel, or typewriter hammer pushes the waxy coating aside, leaving small mounds along the outside and inside of letters and lines. Ink flows through the bared areas of a stencil tissue to transfer images. The tissue structure often causes the printed image to appear with tiny cracks or sometimes rimmed edges. (The former feature is seen with transfer lithography and the latter with letterpress printing.) In certain places in issue 3, letter rims occur.

Typewriting frequently reproduces ribbon dots that distort the edges of nearby letters in a regular pattern, but evenly spaced marks completely external to letters would require penetration of the stencil itself or an impossibly precise scattering of ink during printing.

Photostatic printing on ordinary paper, or photocopying, probably can be ruled out as a reproduction process. The process became available in the 1950s but required use of a specially coated paper until the following decade, when plain-paper copying became possible. Broadly, the process replicates the original on an intermediary medium, such as a drum, by creating an electric charge in the same pattern. That charge is passed to paper and attracts graphite, or toner. A heat process fuses the toner to the sheet, but small bits of graphite often adhere to other areas. Such dots tend to be somewhat irregularly spaced and do not appear as precisely arranged as those adjacent to the letter shown.

These small dots near but not brushing against that letter could have been created by the ink from a typewriter ribbon directly impressed onto an offset plate. A plate carries details to the machine's blanket for transfer to final copies. Many offices and printing shops used offset lithography in the mid-20th century, although photocopying replaced such machines in office settings during the 1960s. Offset lithography required a skilled person to turn out quality work. Importantly, the process required right-reading plates, and such materials could be prepared by typing directly upon them. Addressograph-Multigraph introduced multilith machines for offices in the 1930s; and, by the 1950s, both that firm and A.B. Dick Company sold such units. Like the term "mimeography," "multilith" came into widespread usage for describing offset lithography generally and remains common today; "multigraph" refers to a relief process. ${ }^{21}$

21. Batterham, The Office Copying Revolution, 107-11; William H. Johnson and Louis V. Newkirk, The Graphic Arts, Industrial Arts Education Series (New York: The Macmillan Company, 1942), 88-89. 
Photolithography, like the subset of that process called offset lithography, uses a right-reading original. This is an asset for prepress production by volunteers. Rather than typing onto a plate, the original image can be pieced together from several sources or a duplicate of a previously printed item. The photographic process tends to wash out fine lines or dots without careful exposure; it also thickens lines or bloats letters slightly (in a process called dot gain).

Line photolithography often generates a muddied appearance in areas of solid black; when offset with a blanket, heavy ink coverage sometimes generates a shadow tone as printing continues. Halftone photolithography employs an even screen of black and white dots across entire areas of the print. The appearance of regular dots exclusively next to letters rather than as part of a uniform screen across the text points to line photolithography as a possible printing method.

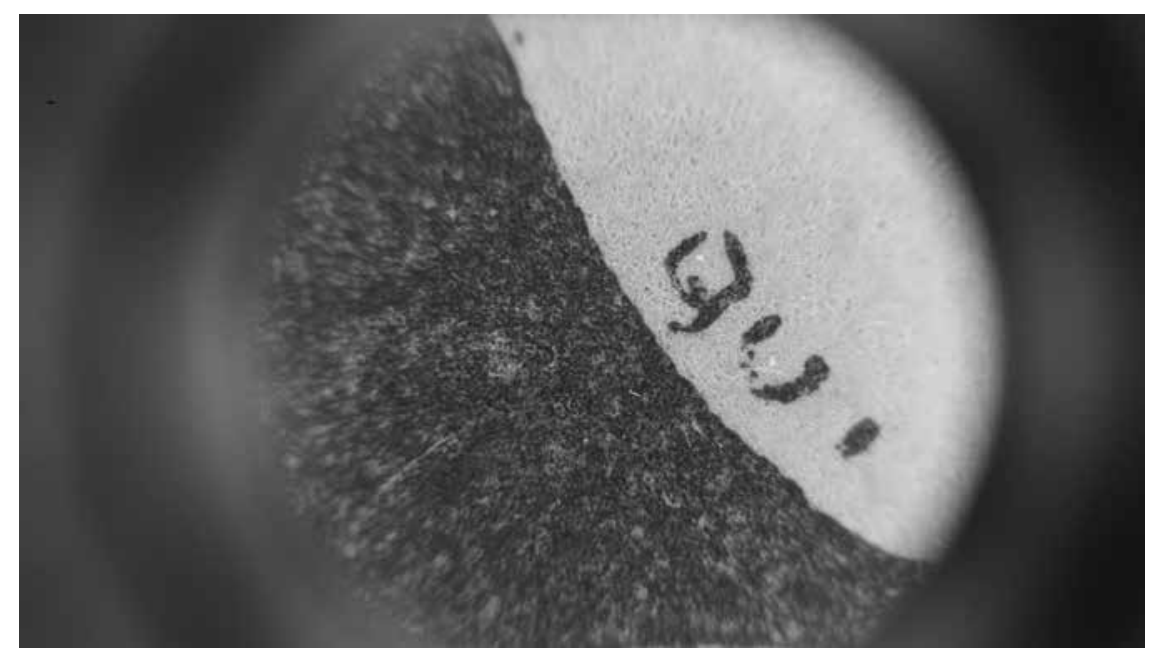

Figure 3. Front cover, December 1956

Although the production process for text pages of issue 3 is far from clear, by issue 7 The Ladder was produced with photolithography. Sample letters for issues 6 and 7 exhibit the puffy look characteristic of photolithography. Ink also lies on the surface of the paper in the latter issue, as is typical for lithography. Issue 6 shows less cleanly the lithographic method, and portions of the publication present challenging identification as well. Detecting offset processes is not possible; however, offset lithography likely was used.

Finally, the wash of uneven black on the cover image of the third issue (see figure 3) also appears to be lithographic. Although the text and covers could have been printed separately, these techniques are compatible with production in a single shop. 


\section{Conclusion}

Volunteer labor and gifts of common supplies rather than machinery often comprise the chief resources of an emerging social movement. Identifying complexity in the technological narrative of the Daughters of Bilitis only further confirms the importance of "sweat equity" and professional exchanges in production of The Ladder. Pragmatic strategies often are necessary to initiate or continue self-publication by community organizations. Rather than a failure to thrive technologically, inconsistency in production practices can indicate resilience and adaptive capability. This very facet of ephemeral publications can challenge curatorial care.

Evidence from archives and artifacts shows the production history of The Ladder to be much more than a continuous stream of mimeographed sheets, but entirely consistent with resources controlled by the organization and its inner circle. Textual and artifact evidence of how the third issue of The Ladder was produced is ambiguous. Skilled DOB members with access to a multilith machine at Macy's may have printed issues as early as December 1956 and through February 1957, or the transition may have occurred one issue later. An accident injuring the print operator and near-discovery of the magazine while it was on press revealed to organizers how precarious clandestine publishing could be. The sixth issue appears to be transitional and may have been produced by an operator less familiar with the publication. By the seventh issue, production shifted to a commercial but friendly relationship with a vendor well known for connections in the gay community, PanGraphic Press. More research into that transition should be conducted.

Production techniques adapted to the needs of the Daughters of Bilitis and a growing national readership may mask the group's technological access. Readers regularly requested back issues of The Ladder, and staff filled such orders whenever possible. The first issues increasingly fell out of print. Announcements in The Ladder during 1957 for a quarterly reprint of the first three issues, and further correspondence stating that the first five issues would be reprinted, point toward the possibility that some copies of the publication available today are not first impressions and were not completed by the original printing process. Rather than a fixture of culture production, mimeography becomes part of a much larger story rather than "the" story.22

Leaders of the Daughters of Bilitis continued to express hope that issues could be rerun by April of 1958. DOB worked on a new printing press arrangement that spring, which, along with the expense of reprinting back issues, caused a delay in the venture, according to correspondence. Were those reprints to be printed from

22. "Quarterly Publication Time Drawing Near," The Ladder 1.6 (March 1957), 15; and "The Quarterly comprised of the first three issues has grown to five...," The Ladder 1.9 (June 1957), 26. 
newly prepared materials or through photolithography? The latter would allow highly accurate reproduction of printed material, without the creation of new stencils. The reprints would have been nearly indistinguishable from original issues, with only slight dot gain between first and second generations. In effect, photolithography would visually adopt the characteristics of the earlier generation's technical process, retelling the first generation's narrative without challenge. ${ }^{23}$

The evidence provided by artifacts intersects with (and can at times challenge) textual, oral, or other records. Periods of technological transition require analysis of a range of reproduction processes. Each represents a constellation of materials, skills, and resources that shape a publication's availability and, ultimately, longevity. It can be quite difficult to ascertain the specific processes used in such periods, and techniques for recognizing each process are only slowly being established. Special collections holdings can, like the volunteers of community movements, become the source for innovation. Archival research can in some cases produce critical information for documenting production processes and associated equipment; in other instances, simply providing images that can be identified as examples of specific processes furthers the study of such print enormously.

The breadth of techniques for reprinting small-run publications points to the importance of provenance for more ephemeral print holdings. For certain publications, this loss of data about the order of printing and relationship between readers and producers can inhibit fuller understanding of how a community navigates its difficult early years. Photolithography, for instance, can obscure the origins of print holdings separated from archival acquisitions. Leaving few fingerprints for detecting the difference between original and reprint, photolithography easily transferred an image to a printing plate, perhaps with only slight swelling of the letters. More documentation on techniques common in the 20th century can assist in properly classifying, cataloging, and caring for niche publications like those in the increasingly important 'zine genre. Close cultural associations between mimeography and alternative publications can and should be examined as part of such analysis.

\section{Bibliographical Essay}

Mimeography and 20th-century duplication processes are increasingly a focus for bibliographers, collectors, and historians, and conservation literature may be one of the better areas for accessing useful information. Ian Batterham's The Office Copying Revolution: History, identification and preservation (Canberra: National Archives of Australia, 2008) contains an "Identification chart for office copying processes” (166-67) with image magnifications. His histories track an exceptional 
range of reproduction techniques, inks, and papers. Research underway by Brian Cassidy promises an important mimeograph-specific guide for future research. For letterpress, intaglio, and lithography, see Bamber Gascoigne's How to Identify Prints: A Complete Guide to Manual and Mechanical Processes from Woodcut to Ink-jet (London: Thames \& Hudson, 1986; 2nd ed., 2004). W.B. Proudfoot, The Origin of Stencil Duplicating (London: Hutchinson \& Co., 1972) remains a valuable source for historical data about inventors and firms, with selected identification images. Barbara J. Rhodes and William W. Streeter reconstruct detailed histories of a range of duplication processes, such as mimeography and its competitors, in Before Photocopying: The Art and History of Mechanical Copying, 1780-1938 (New Castle, Del.: Oak Knoll Press, 1999). For a brief overview of common duplication processes of interest to collection caretakers, see Diane Vogt-O'Connor, "Judging Permanence for Reformatting Projects: Paper and Inks," National Park Service Conserve O Gram 19/14 (September 1995), available at www.nps.gov/history/museum/publications/conserveogram/19-14.pdf.

A.B. Dick Company’s Techniques of Mimeographing (1958 and 1963) provides vendorspecific information; Bill Stencil outlines generic practices and self-production of mimeographic equipment and supplies in his Handbook of Mimeograph Technique (Mena, Ark.: Commonwealth College, 1937). Sources for learning about the range of mid-century duplicator technologies include George A. Stevenson's Graphic Arts Encyclopedia (New York: McGraw-Hill Book Company, 1968); William H. Johnson and Louis V. Newkirk, The Graphic Arts, Industrial Arts Education Series (New York: The Macmillan Company, 1942); and James P. Casey, Pulp and Paper: Chemistry and Chemical Technology, Vol. 3: Paper Testing and Converting, 2nd ed. (New York: Interscience Publishers, 1961).

Online sources have become important in the study of duplication techniques as communities of practice share knowledge about conservation implications, technical practices, and historical data. The Conservation OnLine (CoOL) website by the Foundation of the American Institute for Conservation provides a range of communications about techniques, their identification, and implications for collections care. See http: / / cool.conservation-us.org/. (Peter Graham’s 1995 ExLibris posting on the subject "Mimeograph and its competitors" is temporarily unavailable during the migration of CoOL mailing list archives [Feb. 10, 2014].) Luis Nadeau compiles information in his two-volume work Encyclopedia of Printing, Photographic, and Photomechanical Processes (Fredericton, N.B.: Atelier Luis Nadeau, 1989-90). Nadeau's "Office Copying \& Printing Processes," an excerpt from Guide to the Identification of Prints and Photographs (2002), is available at http: / / cool.conservation-us.org/ byauth/nadeau/copyingprocesses.pdf. The Dead Media Project website provides crowd-sourced documentation (www.deadmedia.org/) inspired by Bruce Sterling's 
"Dead Media Manifesto," although the e-mail list has been inactive for some time. The Early Office Museum maintains an extensive site noting antique copying and other equipment (www.officemuseum.com/).

On related topics, Kevin Laurence summarizes sources for carbon paper in "The Exciting History of Carbon Paper!” (www.kevinlaurence.net/essays/cc.php), and an exhaustive history of writing ink can be found in David N. Carvalho, Forty Centuries of Ink; or, A Chronological Narrative Concerning Ink and Its Backgrounds... (New York: Banks Law Publishing Co., 1904), available as Forty Centuries of Ink (Seattle: The World Wide SchoolTM, 1999) at www.worldwideschool.org/library/books/ tech/printing/fortycenturiesofink/toc.html. 